\title{
Human impact on mid- and late Holocene vegetation in south Cumbria, UK
}

\author{
Guy Wimble, Colin E. Wells, and David Hodgkinson
}

Unfortunately, this page 31 was missing in: Veget Hist Archaeobot (2000) 9:17-30

Mercer R, Tipping R (1994) The prehistory of soil erosion in the northern and eastern Cheviot Hills, Anglo-Scottish borders. In: Foster S, Smout TC (eds), The history of soils and field systems. Scottish Cultural Press, Aberdeen, pp. 1-25

Merrifield DL, Moore PD (1974) Prehistoric human activity and blanket peat initiation on Exmoor. Nature 250: 439-441

Middleton R (1996) The Neolithic and Bronze Age. In: Newman $\mathrm{R}$ (ed) The archaeology of Lancashire. Lancaster: Lancaster University Archaeological Unit.

Middleton R, Wells CE, Huckerby E (1995) The wetlands of north Lancashire. Lancaster Imprints, Lancaster

Moore PD (1968) Human influence upon vegetational history in north Cardiganshire. Nature 217: 1006-1009

Merryfield DL, Moore PD (1974) Prehistoric human activity and blanket peat initiation on Exmoor. Nature 250: 439-441

Munn Rankin W (1910) The peat mosses of Lonsdale. Naturalist 119: 153

Oldfield F (1963) Pollen analysis and man's role in the ecological history of the south-east Lake District. Geogr Ann 45: 23-40

Oldfield F, Statham DC (1963) Pollen-analytical data from Urswick Tarn and Ellerside Moss, north Lancashire. New Phytol 62: 53-66

Olivier ACH (1987) Excavation of a Bronze Age funerary cairn at Manor Farm, near Borwick, north Lancashire. Proc Prehistoric Soc 53: $129-186$

Pearsall WH, Pennington W (1973) The Lake District. Collins, London

Pennington, W (1964) Pollen analysis from the deposits of six upland tarns in the Lake District. Phil Trans R Soc London B 248: $205-244$

Pennington W (1970) Vegetation history in north-west England. In: Walker D, West RG (eds) Studies in the vegetational history of the British Isles. Cambridge University Press, Cambridge, pp. 41-80

Pennington W (1997) Vegetational history. In: Halliday G (ed) A flora of Cumbria. Lancaster University, Lancaster, pp. 42-50

Pigott CD, Huntley JD (1978) Factors controlling the distribution of Tilia cordata at the northern limit of its geographical range. 1. Distribution in north-west England. New Phytol 81: 429. 441

Quartermaine J (1994) Torver High Common, Cumbria, archaeological survey. Lancaster University Archaeological Unit, Lancaster

Quartermaine J (1995) Torver Low and Blawith Commons, Cumbria, archaeological survey. Lancaster University Archaeological Unit, Lancaster

Rackham O (1980) Ancient woodland: its history, vegetation and uses in England. Cambridge University Press, Cambridge

Roe FES (1976) Typology of stone implements with shaftholes. In: Clough TH, Cummins WA (eds) Stone axe studies. Coun British Archaeol Res Rep 23, CBA, London
Shotter DA (1984) Roman north-west England, Lancaster University, Lancaster

Shotter DA (1994) Rome and the Brigantes: early hostilities. Trans Cumberland Westmorland Achaeol Antiq Soc NS 94: 21-34

Shotter DA (1997) Romans and Britons in north-west England. Lancaster University, Lancaster

Simmons IG (1964) Pollen diagrams from Dartmoor. New Phytol 53: $164-180$

Simmons IG (1969) Environment and early man on Dartmoor, Devon, England. Proc Prehistoric Soc 35: 203-219

Smith AG (1959) The mires of south-western Westmorland. New Phytol 58: 105-127

Stuiver M, Reimer PJ (1993) Extended 14C data base and revised Calib 3.0 14C calibration program. Radiocarbon 35: 215-230

Tipping R (1994) Williamson's Moss: palynological evidence for the Mesolithic-Neolithic transition. In: Boardman J, Walden J (eds) Cumbria Field Guide. Quaternary Research Association, Oxford, pp. 104-128

Tipping R (1995) Holocene evolution of a lowland Scottish landscape: Kirkpatrick Fleming. Part II, regional vegetation and land-use change. Holocene 5: 83-96

Turnbull P, Walsh D (1996) A Beaker burial in Levens Park, Trans Cumberland Westmorland Antiq Archaeol Soc, NS 96: 13-26

Turner J (1964) The anthropogenic factor in vegetation history. New Phytol 63: 73-89

Turner J (1965) A contribution to the history of forest clearance. Proc R Soc B 161: 343-354

Twigger SN (1988) Late Holocene palaeoecology and environmental archaeology of six lowland lakes and bogs in north Shropshire. $\mathrm{PhD}$ thesis, Southampton university

Walker D (1965) The post-Glacial period in the Langdale Fells, English Lake District. New Phytol 64: 488-510

Walker D (1966) The late Quaternary history of the Cumberland lowland. Phil Trans R Soc B 251: 1-120

Waterhouse $J$ (1985) The stone circles of Cumbria. Philimore, Chichester

Weber CA (1900) Über die Moore, mit besonderer Berücksichtigung, der zwischen Unterweser und Unterelbe liegenden. Jahresber Männer Morgenstern 3: 3-23

Wells C, Huckerby E, Hall V (1997) Mid - and late - Holocene vegetation history and tephra studies at Fenton Cottage, Lancashire, UK. Veget Hist Archaeobot 6: 153-166

Winchester AJL (1987) Landscape and society in medieval Cumbria. Donald, Edinburgh

Wymer JJ (1981) The Palaeolithic. In Simmons IG, Tooley MJ (eds) The environment in British prehistory. Duckworth, London, pp. 49-81 